\title{
Development and Validation of a Real-Time PCR Assay for the Quantification of Verticillium dahliae in Potato
}

J. S. Pasche and I. Mallik, Department of Plant Pathology, North Dakota State University, Fargo 58108; N. R. Anderson, Department of Botany and Plant Pathology, Purdue University, West Lafayette, IN 47907; and N. C. Gudmestad, Department of Plant Pathology, North Dakota State University \begin{abstract}
of Verticillium dahliae in potato. Plant Dis. 97:608-618.
An increase in the stringency for higher quality potato tubers and restrictions on the use of soil fumigants, among other factors, has garnered renewed interest in Verticillium wilt, particularly in russetskinned cultivars grown for processing. In response to the needs of producers, breeders have increased efforts in the development of potato cultivars with resistance to Verticillium dahliae Kleb., the primary cause of Verticillium wilt. These efforts have resulted in the release of numerous russet-skinned cultivars with purported resistance to the pathogen. However, because efficient and effective methods to screen germplasm for true resistance do not exist, breeders typically have reported resistance based on the development of wilt symptoms alone. The studies reported here demonstrate the efficiency and practicality of a QPCR method for quantification of $V$. dahliae in potato stem tissue. This method, developed to detect the target trypsin protease gene of the pathogen, was compared with traditional methods for $V$. dahliae quantification which involve plating stem tissue or sap onto semi-selective media, as well as to a recently developed QPCR assay which amplifies
\end{abstract}

Abstract

Pasche, J. S., Mallik, I., Anderson, N. R., and Gudmestad, N. C. 2013. Development and validation of a real-time PCR assay for the quantification

a region of the $\beta$-tubulin gene of $V$. dahliae. The QPCR assay developed in the studies reported here was demonstrated to be sensitive to $0.25 \mathrm{pg}$ of DNA. Use of the duplex real-time PCR assay, utilizing the potato actin gene to normalize quantification, resulted in clearer differentiation of levels of resistance among eight russet-skinned potato cultivars inoculated in greenhouse trials when compared with traditional plating assays. However, relative levels of resistance among cultivars were similar between traditional plating and QPCR methods, resulting in correlation coefficients greater than 0.93 . The assay described here also detected the pathogen in inoculated stem tissue at higher frequencies than both traditional plating assays and a previously developed QPCR assay. The QPCR assay developed here demonstrates rapid, efficient, and accurate quantification of $V$. dahliae, providing a tool amenable for use by breeding programs on large numbers of clones and selections, and will aid researchers evaluating other control strategies for Verticillium wilt.
Verticillium wilt in U.S. potato (Solanum tuberosum L.) production is caused largely by Verticillium dahliae Kleb., although $V$. albo-atrum Reinke \& Berthold may be associated with the disease in cooler climates $(15,60)$. V. dahliae, either alone or in conjunction with other fungal pathogens, including Fusarium spp. and Colletotrichum coccodes (Wallr.) S. Hughes, and the root-lesion nematode Pratylenchus penetrans (Cobb) Sher \& Allen, may be the primary cause of economic losses in the potato industry in the United States $(12,15,49,56,59)$. This is due not only to yield reductions but also to losses in tuber size and quality from vascular discoloration, as well as losses from the cost of control, primarily soil fumigation using metam sodium $(12,27)$. Symptoms of Verticillium wilt begin to appear at the base of the plant and move acropetally as the season progresses $(59,62)$. The symptoms of general plant wilting can be impossible to differentiate from natural senescence. However, unilateral wilting, the result of differential colonization of individual vascular bundles, and the erect posture of dead plants infected with $V$. dahliae are diagnostic of Verticillium wilt $(14,62)$. Discoloration often is present in stem as well as tuber vascular tissue.

Microsclerotia are the main infective propagules of $V$. dahliae under field conditions and are reported to survive in the soil for up to 14 years (69). Microsclerotia germinate in the presence of susceptible host plants to infect near the zone of elongation of root

Corresponding author: N. C. Gudmestad,

E-mail: Neil.Gudmestad@ndsu.edu

Accepted for publication 4 December 2012.

http://dx.doi.org/10.1094/PDIS-06-12-0554-RE

(C) 2013 The American Phytopathological Society tips $(6,26)$. Any movement of soil into a field subsequently may result in the introduction of the pathogen into noninfested soil $(58,62)$. Initial introductions of $V$. dahliae into fields often are isolated but, when susceptible potato cultivars are grown, infected stem tissue serves as inoculum for subsequent crops, returning microsclerotia to the soil after harvest (62). In potato, $100 \%$ stem infection was recorded at soil infestation levels of 6 to 10 microsclerotia/g in Wisconsin (49), whereas, 8 and 18 to 23 microsclerotia/g of soil have been documented as the economic thresholds in Idaho and Colorado, respectively $(17,50)$. Although the relationship between disease incidence and microsclerotial concentration differ among cultivars, environmental conditions, and cropping practices, the reduction of microsclerotia in the soil is paramount in mitigating the effects of this monocyclic pathogen in the absence of genetic resistance $(5,70)$.

Several factors have led to the increased importance of Verticillium wilt, including reduced tillage and shorter rotations between potato crops, higher value placed on tuber quality, and an increase in use restrictions of soil fumigants - most recently, metam sodium $(12,38,63)$. Soil fumigation using metam sodium is effective and widely used but also is expensive and detrimental to the environment $(12,38,58)$. Environmental Protection Agency restrictions on the application of metam sodium are mounting and will result in limiting usage by growers (38). Verticillium wilt management also involves reducing soil pathogen populations as well as limiting the effect the pathogen has on the host. Control measures which focus on reducing populations in the soil, in addition to soil fumigation, include crop rotation, tillage, and solarization $(12,17,58,63,66)$. Control measures that focus on minimizing infection and the effects of the pathogen on the host include nutrient and water management, as well as the use of resistant cultivars $(12,18,58)$. Because of the general lack of resistance in commonly grown cultivars, some cultural management practices can aid in decreas- 
ing the severity of Verticillium wilt; however, these measures are not adequate to reduce disease to acceptable levels $(30,32)$. V. dahliae resistance has been identified in wild Solanum spp., breeding clones, and commercial cultivars $(9,10,13,16,30,31)$. Unfortunately, few cultivars exhibiting $V$. dahliae resistance currently meet industry standards and, therefore, growers rely heavily on soil fumigation for effective control of Verticillium wilt $(58,63)$.

Several recently released cultivars have been reported to exhibit resistance to Verticillium wilt based on symptom expression but, in many instances, no attempts were made to quantify the level of pathogen present to determine if the host response was one of true resistance or tolerance $(33,35-37,44-46,51-55,65)$. Additionally, symptom expression can be very limited and difficult to discern from natural senescence, often resulting in incorrect diagnoses (12). Several research studies have described the use of fresh and dried plating techniques to evaluate $V$. dahliae resistance and control strategies $(9,16,24,28-32,49)$. Although recent research comparing traditional plating methods of pathogen quantification with visual wilt symptoms appears to be accurate and reliable, these methodologies are time and labor intensive $(4,28,29)$. This, in turn, represents an increase in the need for accurate and rapid assays to detect the pathogen in host tissue in order to define the exact nature of the host-parasite interaction. A quantitative real-time polymerase chain reaction (PCR) assay would significantly reduce the time and labor required to quantify the $S$. tuberosum-V. dahliae interaction.

PCR assays, including traditional endpoint detection and quantification as well as real-time quantification, have been developed for $V$. dahliae $(1,11,25,34,39-42,48,57)$. The internal transcribed spacer (ITS) regions of $V$. dahliae and $V$. albo-atrum were utilized for the development of endpoint PCR assays for quantifying $V$. albo-atrum in alfalfa and $V$. dahliae in sunflower $(25,48)$. An additional endpoint PCR assay, also using the ITS region, was developed and utilized to distinguish Verticillium spp. in soil and field-grown potato (39) and, subsequently, to quantify $V$. dahliae in potato breeding clones and cultivars (11). Random amplified polymorphic DNA polymorphisms were used to develop further primers to differentiate $V$. dahliae pathotypes of cotton and olive $(40-42,57)$, as well as to quantify fungal biomass in potato in an endpoint PCR assay utilizing a competitive internal control (34). The first real-time QPCR assays were employed to quantify $V$. dahliae in olive and potato, utilizing SYBR-Green (40) and Plexor Q-PCR (1) platforms, respectively. Primers for the latter assay were developed to amplify a region in the $\beta$-tubulin 2 gene of the pathogen, while using primers developed for the actin (act) gene of potato to normalize the quantification of $V$. dahliae. Although the duplex assay developed to quantify $V$. dahliae in potato (1) recently has been used to quantify the pathogen in spinach seed (22), it has not been used in more recent studies on this host-parasite interaction in potato despite the fact that many of these studies involve the same authors $(4,20,21,28,29)$, strongly suggesting that further improvement of a QPCR method is justified.

Each of these PCR assays improved upon detection of V. dahliae and advanced the knowledge of Verticillium wilt in numerous host-pathosystems. However, for quantification of fungal biomass, none has displayed sufficient utility to be adopted successfully by researchers as a replacement for time-consuming and laborious traditional plating assays for potato $(4,20,21,28,29)$. Therefore, the objectives of this research were to develop a real-time PCR assay, including a reference gene for normalizing the quantification of $V$. dahliae in planta. This real-time PCR assay will be compared with pathogen levels determined by traditional plating methods and a previously developed QPCR method (1) in potato stem sections produced under greenhouse conditions.

\section{Materials and Methods}

V. dahliae isolates culture and maintenance. A combination of four $V$. dahliae isolates originating from potato produced in Minnesota was used to develop, perform, and validate QPCR assays. Two isolates (VD03UM1 and VD03UM2) were provided by Dr. Jim
Bradeen, Department of Plant Pathology University of Minnesota, and were isolated from potato plants grown in research plots in central Minnesota during the 2003 growing season. The remaining two (VD05MNH5 and VD04MN1-3) were recovered from potato tissue grown in commercial potato fields in central Minnesota in 2005. Stem sections were washed free of soil and surface sterilized in a $0.6 \% \mathrm{NaOCl}$ solution for $10 \mathrm{~min}$. Disks, approximately 3 to 4 $\mathrm{mm}$ wide, were plated onto solid medium containing $7 \%(\mathrm{vol} / \mathrm{vol})$ ethyl alcohol and 1.5\% (wt/vol) agar (EtOH agar). Plates were incubated in the dark for 5 to 10 days and fungal isolation was completed via hyphal tip methods. All four isolates were determined to belong to vegetative compatibility group 4B. Isolates were preserved in long-term storage via transfer onto $10 \%$ clarified V8 juice agar medium (CV8) (43) overlaid with two layers of sterilized Whatman number 1 filter paper for approximately 3 to 4 weeks or until the filter paper was completely colonized. The top layer of filter paper was removed, cut into small pieces, placed into 2-ml Nalgene cryogenic vials (Thermo Fisher Scientific) under sterile conditions, dried for 2 days, and stored at $-80^{\circ} \mathrm{C}$ for future use.

Greenhouse production of infected plant material. Plants of eight russet-skinned potato cultivars, including susceptible ('Russet Norkotah') and resistant ('Ranger Russet') controls, were inoculated with $V$. dahliae and grown under greenhouse conditions (Table 1). The remaining six cultivars were reported to have some level of resistance to Verticillium wilt $(28,45,51,52,55$; A. Thompson, unpublished). The four previously described isolates of $V$. dahliae were grown in liquid $10 \% \mathrm{CV} 8$ media for 7 to 10 days under constant shaking at $22 \pm 2^{\circ} \mathrm{C}$. Fungal material was filtered through two layers of sterile cheesecloth to remove mycelium and the conidial concentrations were standardized to $1.0 \times 10^{5}$ conidia/ml in sterile water with the aid of a hemacytometer. Spore suspensions were combined at equal volumes of each isolate to produce an inoculum suspension.

In all, 10 plants in each of four replicates (40 total plants) of all eight cultivars were inoculated, while 10 were used as noninoculated controls, in each of three greenhouse trials. Portions of certified seed tubers $2 \mathrm{~cm}$ in diameter containing one eye were excised and suberized at $55^{\circ} \mathrm{C}$ in 80 to $85 \%$ relative humidity for $48 \mathrm{~h}$ and planted into $8-\mathrm{cm}$ pots containing Sunshine potting mixture of peat, vermiculite, and perlite (1:1:1, vol/vol/vol) (Sun-Gro Horticulture Canada, Ltd.). Plants were arranged in a randomized complete block design and grown with $16 \mathrm{~h}$ of light for 5 weeks before carefully being removed from these pots. Roots were washed free of soil under running tap water and soaked in the inoculum suspension for $10 \mathrm{~min}$. Noninoculated plants were washed in the same manner as inoculated plants and soaked in sterile water. All plants were transplanted immediately into $20-\mathrm{cm}$ pots containing a $1: 1$ mixture of Sunshine Mix and Scotts Premium Topsoil (The Scotts Miracle-Gro Company).

Extraction of total genomic DNA. Total genomic DNA was extracted from spores and mycelium of the four previously described isolates of $V$. dahliae grown in liquid $10 \% \mathrm{CV} 8$ media for 7 to 10 days under constant shaking at $22 \pm 2{ }^{\circ} \mathrm{C}$. Media was removed via

Table 1. Russet-skinned cultivars evaluated for resistance to Verticillium dahliae in three greenhouse trials, and previously reported level of genetic resistance

\begin{tabular}{lll}
\hline Cultivar & Resistance rating $^{\mathbf{y}}$ & Reference \\
\hline Russet Norkotah & Susceptible check & 30 \\
Ranger Russet & Resistant check & 30 \\
Russet Burbank & MS/MR & 30 \\
Umatilla Russet & MS/MR & 44 \\
Dakota Trailblazer & Very resistant & Thompson ${ }^{\text {; } ~ 30 ~}$ \\
Bannock Russet & Very resistant & 51 \\
Alturas & Very resistant & 52 \\
Premier Russet & MR & 55 \\
\hline
\end{tabular}

y MS = moderately susceptible and MR = moderately resistant.

z A. L. Thompson, unpublished. 
vacuum filtration, fungal material was freeze dried, and DNA was extracted using the DNeasy Plant Mini Kit (Qiagen Inc.) following the manufacturer's instructions. DNA quality and quantity was assessed for each of the four isolates individually using a NanoDrop 2000 (NanoDrop Technologies, LLC). Total genomic DNA was extracted from inoculated and noninoculated stem segments excised from the basal region using the FastDNA Spin Kit (MP Biomedicals) following the manufacturer's instructions. Prior to DNA extraction, $150 \mathrm{mg}$ of fresh stem tissue was pulverized for $45 \mathrm{~s}$ using an MP FastPrep-24. Serial dilutions of each fungal and stem DNA extract were performed in RNase- and DNase-free glass-distilled water (Teknova) prior to use in PCR reactions.

Primer and probe development. Real-time PCR primers and probe were developed from the trypsin protease gene (VTPl) of $V$. dahliae (19) for quantification of fungal biomass in planta. A pair of forward and reverse primers was designed using Primer3 from the National Center for Biotechnology Information (NCBI) GenBank accession number AY354459. These oligonucleotide primers, designated VTP1-2F and VTP1-2R, amplify a 155-bp fragment of the $V T P 1$ gene (Table 2). The corresponding hybridization probe also was designed using Primer3 and designated VTP1-2P. This probe was labeled at the $5^{\prime}$-terminal nucleotide with hexachlorofluorescein phosphoramidite (HEX) reporter dye and at the $3^{\prime}$ terminal nucleotide with Black Hole Quencher (BHQ)-1. Sensitivity of the primer set was evaluated using conventional, endpoint PCR reactions performed on 10-fold serial dilutions of DNA extracted from fungal cultures adjusted to a concentration of 25 $\mathrm{ng} / \mu \mathrm{l}$. Sensitivity also was evaluated using 10 -fold serial dilutions of DNA extracted from two naturally infected stem samples starting at concentrations of 68 and $86 \mathrm{ng} / \mu \mathrm{l}$, respectively. DNA extractions were performed as described above and selected amplicons from each of the PCR reactions were sequenced. Endpoint PCR reaction conditions were $2 \mathrm{~min}$ at $95^{\circ} \mathrm{C}$ followed by 40 cycles of $30 \mathrm{~s}$ at $95^{\circ} \mathrm{C}, 60 \mathrm{~s}$ at $58^{\circ} \mathrm{C}$, and $30 \mathrm{~s}$ at $72^{\circ} \mathrm{C}$. Primer/probe specificity was evaluated via in silico analyses using NCBI Primer Blast to ensure that the amplicon was unique to $V$. dahliae. Additionally, specificity of the primer set was evaluated using PCR reactions performed against numerous fungal and bacterial pathogens and saprophytes of potato, and several Verticillium spp. (Table 3). Bacterial species were grown in liquid nutrient broth yeast extract (NBY) medium inoculated with bacteria from $-80^{\circ} \mathrm{C}$ storage and grown for 1 to 3 days with shaking at $22 \pm 2^{\circ} \mathrm{C}$. Bacterial DNA was extracted using Wizard Genomic DNA Purification Kit (catalog number A1120; Promega Corp.) following the manufacturer's instructions. Prior to conversion into a real-time PCR format, VTP1-2 primers were evaluated using the SYBR Green detection system to ensure that primer dimers and nonspecific binding did not affect target gene quantification. All assays were optimized for $\mathrm{MgCl}_{2}, \mathrm{dNTP}$, and primer concentrations, as well as annealing temperature for use in a $25-\mu l$ reaction.

Development, optimization, and validation of a duplex QPCR assay. The PCR assay developed for the target VTPl gene

Table 2. Real-time polymerase chain reaction primers and probes designed for quantification of the trypsin protease gene (VTP1) of Verticillium dahliae and the reference actin gene in potato

\begin{tabular}{llcllc}
\hline Primer/ probe & Target organism & Gene target & Sense & \multicolumn{1}{c}{ Sequence $\left(\mathbf{5}^{\prime} \mathbf{- 3}^{\prime}\right)$} & Amplicon size $(\mathbf{b p})$ \\
\hline VTP1-2F & Verticillium dahliae & $V T P 1^{\mathrm{x}}$ & Forward & CTC GAT CGT CGT CAA CC & 155 \\
VTP1-2R & $\ldots$ & $\ldots$ & Reverse & TGG TGG TGA GAG TGT TG & $\ldots$ \\
VTP1-2P & $\ldots$ & $\ldots$ & Probe & HEX/TAC GAC AAC GAC TTC GCC ATC/3BHQ_1 & $\ldots$ \\
PotAct-F & Solanum tuberosum & $a c t^{\mathrm{z}}$ & Forward & TGA ACA CGG AAT TGT CAG CA & 123 \\
PotAct-R & $\ldots$ & $\ldots$ & Reverse & GGG GTT AAG SGG GGC TTC AG & $\ldots$ \\
PotAct-P & $\ldots$ & $\ldots$ & Probe & Cy5/ACA ATG AGC TTC GTG TTG CC/3BHQ_2 & $\ldots$ \\
\hline
\end{tabular}

${ }^{\mathrm{x}}$ GenBank accession number AY354459.

y PotAct primers originally described by Atallah and Stevenson (2).

${ }^{\mathrm{z}}$ GenBank accession number X55751.

Table 3. Specificity of real-time polymerase chain reaction assays used for the quantification of Verticillium dahliae

\begin{tabular}{|c|c|c|c|}
\hline Microorganism species & Potato disease & VTP1-2 & PotAct $^{\mathrm{x}}$ \\
\hline Alternaria alternata & Brown spot & - & - \\
\hline A. solani & Early blight & - & - \\
\hline Colletotrichum coccodes & Black dot & - & - \\
\hline Fusarium graminearum & Fusarium dry rot and wilt & - & - \\
\hline F. oxysporum & Fusarium dry rot and wilt & - & - \\
\hline F. sambucinum & Fusarium dry rot and wilt & - & - \\
\hline F. solani & Fusarium dry rot and wilt & - & - \\
\hline Rhizoctonia solani & Rhizoctonia canker and black scurf & - & - \\
\hline Sclerotinia sclerotiorum & White mold & - & - \\
\hline Pythium ultimum & Leak & - & - \\
\hline Phytophthora erythroseptica & Pink rot & - & - \\
\hline P. infestans & Late blight & - & - \\
\hline P. nicotianae & Pink rot/late blight & - & _- \\
\hline Spongospora subteranea & Pitted scab & - & - \\
\hline Clavibacter michiganense subsp. sepedonicum & Bacterial ring rot & - & - \\
\hline Pectobacterium carotovorum subsp. atrospetica & Blackleg & - & - \\
\hline P. carotovorum subsp. carotovorum & Soft rot & - & - \\
\hline Serratia marcescens & Ubiquitous bacterium often found on potato plants & - & - \\
\hline Streptomyces scabies & Common scab & - & - \\
\hline Verticillium dahliae & Verticillium wilt & + & - \\
\hline V. albo-atrum & Verticillium wilt & - & - \\
\hline V. isaacii $^{\mathrm{y}}$ & $\ldots$ & - & - \\
\hline V. klebahnii ${ }^{\mathrm{y}}$ & $\ldots$ & - & - \\
\hline V. longisporum ${ }^{\mathrm{y}, \mathrm{z}}$ & $\ldots$ & + & - \\
\hline Healthy potato & $\ldots$ & - & + \\
\hline PCR-grade water & $\ldots$ & - & - \\
\hline
\end{tabular}

${ }^{x}$ Positive or negative results denoted as + or - , respectively. Samples with quantification cycle values greater than 35 are reported as negative.

y DNA kindly provided by K. V. Subbarao.

${ }^{z}$ DNA kindly provided by S. Klosterman. 
using VTP1-2F/R/P was duplexed with primers and probe for the potato act gene (2). Primers previously were developed to amplify a 123-bp region of the act gene (2). Because the original assay using these primers was developed for the Plexor Q-PCR System, the hybridization probe PotAct-P was designed using Primer3 from the act gene sequence described by NCBI GenBank accession number X55751 to enable multiplexing with the VTP1-2 assay (Table 2). This probe was labeled at the $5^{\prime}$-terminal nucleotide with Cy5 reporter dye and at the $3^{\prime}$-terminal nucleotide with BHQ-2. Cycling conditions for this duplex assay were optimized experimentally with $2 \mathrm{~min}$ at $95^{\circ} \mathrm{C}$ followed by 40 cycles of $30 \mathrm{~s}$ at $95^{\circ} \mathrm{C}$, $60 \mathrm{~s}$ at $58^{\circ} \mathrm{C}$, and $30 \mathrm{~s}$ at $72^{\circ} \mathrm{C}$, with data capture after the annealing step carried out in a Stratagene Mx3005P using polypropylene nonskirted QPCR 96-well tube plates (Agilent Technologies, Inc.). Amplification and quantification of the VTP1 gene was achieved using $0.5 \mu \mathrm{M}$ VTP1-2 forward and VTP1-2 reverse primers, 0.4 $\mu \mathrm{M}$ VTP1-2 hybridization probe, $0.6 \mu \mathrm{M}$ PotAct forward and PotAct reverse primers, $0.1 \mu \mathrm{M}$ PotAct hybridization probe, 1.5 $\mathrm{mM} \mathrm{MgCl} 2,0.2 \mathrm{mM}$ dNTP, $1 \times$ polymerase buffer, 1 unit of GoTaq DNA polymerase, and $2.0 \mu \mathrm{l}$ of template DNA in a $25-\mu \mathrm{l}$ reaction. The host act gene was used for normalizing quantification of the VTP1 gene in the duplex format. PCR efficiency was evaluated with each primer-probe combination individually and in combination to ensure that the addition of the reference gene would not affect target gene quantification.

Validation of target gene amplification was achieved using total genomic DNA extracted from mycelia and spores of four isolates of $V$. dahliae, as described previously. Extracts from each of the $V$. dahliae isolates were diluted to $25 \mathrm{ng} / \mu \mathrm{l}$, equal volumes of DNA from each were combined, and the resulting solution was diluted serially 10-fold in PCR-grade water over six orders of magnitude. For validation of the duplex assay, DNA from the host was obtained from disease-free tissue-culture-derived, greenhouse-reared plants. Additionally, the same series of dilutions from two stem samples, starting with total genomic DNA at 68 and $86 \mathrm{ng} / \mu \mathrm{l}$, were used for validation of both duplex endpoint and QPCR assays. QPCR assays for all serially diluted material were performed in triplicate. The final validation step involved comparing the quantification of the target pathogen derived from the duplex QPCR assay using primers VTP1-2F and -R and probe VTP1-2P, in conjunction with normalizing primers PotActF and $-\mathrm{R}$ and probe PotActP, to traditional plating methods in potato stem tissue generated in three greenhouse trials containing 10 inoculated and 10 noninoculated plants of eight cultivars in four replicates $(1,920$ total plants), as described above. All QPCR reactions evaluating greenhouse-derived stems were performed in duplicate. A standard curve for both the pathogen VTP1 and the host act normalizing gene was developed to allow quantification of the PCR product from the VTP1 gene, as well as account for differences in DNA extraction and PCR efficiency. Dilution series of both the fungal and tissue-culture-derived stem DNA were included in duplicate on each PCR plate as internal positive controls, as well as quantification standards.

Comparison of traditional plating to PCR quantification of $\boldsymbol{V}$. dahliae in planta. A portion of a single stem per plant, extending from approximately $2.5 \mathrm{~cm}$ below and $18 \mathrm{~cm}$ above the soil line, was harvested from each of 5 plants of each cultivar, inoculation type, and replicate (320 plants total) at 8 and 11 weeks after inoculation (WAI; 28). Stem segments were surface sterilized in a $10 \%$ household bleach solution and air dried. A longitudinal crosssection of stem tissue weighing approximately $1 \mathrm{~g}$ was excised from the basal region of each stem segment and placed into a plastic bag, and sterile distilled water was added at a 1:1 (wt/vol) ratio. Stem segments then were crushed and $50 \mu \mathrm{l}$ were spread onto solid Sorenson's NP-10 semiselective media (23). Plates were incubated in the dark for 4 to 5 weeks, read directly under $\times 60$ magnification with the aid a stereo-microscope, and the number of $V$. dahliae CFU per gram of potato stem tissue was calculated.

Comparison of VTP1-2 and VertBt-Plexor assays. The duplex real-time PCR assay developed for the quantification of $V$. dahliae using the $V T P 1$ gene was compared with the previously developed duplex QPCR assay specific to the $\beta$-tubulin 2 gene (1). DNA was extracted from mycelia and conidia of four $V$. dahliae isolates, and from inoculated stem tissue of five Russet Norkotah plants, as described above. DNA from each sample subsequently was adjusted to $25 \mathrm{ng} / \mu \mathrm{l}$ and diluted serially 10 -fold in PCR-grade water over six orders of magnitude, and differences in sensitivity between the two real-time PCR assays were evaluated. Further comparative evaluations were performed on nondiluted DNA extracted from greenhouse-derived stem tissue of 'Umatilla Russet' inoculated with $V$. dahliae from 5 stems in each of four replicates (20 stems total).

Evaluation of Verticillium wilt severity. Percent Verticillium wilt severity was recorded on a weekly basis beginning $5 \mathrm{WAI}$ and continuing for 5 to 8 weeks. The area under the wilt progress curve (AUWPC) was calculated from weekly Verticillium wilt severity data (64) as:

$$
\mathrm{AUWPC}=\sum_{i=1}^{n}[(W i+1+W i) / 2](t i+1-t i)
$$

where $n=$ total number of observations, $W i=$ percent wilt severity at the $i$ th observation, and $t i=$ time in days at the $i$ th observation. To permit comparisons across trials, AUWPC values were standardized by dividing the AUWPC values by the total area of the graph for each treatment-replicate-trial combination, resulting in the relative (R)AUWPC. Additionally, RNA was extracted and foliage (67) from each cultivar in all three greenhouse trials was tested for the presence of Tomato spotted wilt virus (TSWV) using reverse-transcription PCR primers TSWV 1 and 2 (47), as well as forward (S1983) and reverse (S2767) primers (67), also specific for TSWV.

Statistical analyses. Primer and probe optimization and validation were evaluated by comparing slopes and intercepts of linear regressions resulting from serial 10 -fold dilutions. These comparisons were performed across $V$. dahliae isolates to the corresponding overall regression line using random coefficients models. The Bonferroni adjustment was utilized to control the overall familywise type I error $(\alpha=0.05)$ for comparisons across all parameters (slopes and intercepts; 68). Additionally, an analysis of covariance was performed to compare linear regressions developed from VTP1-2F/R/P in simplex and duplex QPCR assays. All QPCR reactions performed to validate the VTP1-2 assay were run in triplicate. $V$. dahliae stem colonization data from three greenhouse trials were transformed using cube-root transformations to meet normality assumptions for the analyses of variance (ANOVA). Data then were combined based on variance homogeneity and the interaction of trial-treatment effect. ANOVA were performed for percentage wilt severity, cube-root-transformed $V$. dahliae CFU per gram of stem tissue, and milligrams of $V$. dahliae per gram of $S$. tuberosum stem tissue. Means were separated using Fisher's protected least significant differences test $(\alpha=0.05)$. Pearson's correlation analyses were performed to show the relationship between $V$. dahliae in milligrams per gram of $S$. tuberosum DNA and $V$. dahliae CFU per gram of stem tissue results from traditional plating assays. The $\chi^{2}$ tests of homogeneity were used to compare the frequency of detection of $V$. dahliae in inoculated stem tissue between QPCR assays developed to the VTP1 and $\beta$-tubulin genes. Fisher's exact tests also were used because only 20 samples were evaluated, a marginal sample size to meet underlying assumptions of the $\chi^{2}$ test $(\alpha=0.05)$.

\section{Results}

Primer and probe development. Following optimization, conventional PCR assays with primers VTP1-2F/R and PotActF/R were sensitive to $25 \mathrm{pg}$ of fungal DNA (Fig. 1A) and total genomic potato stem DNA, respectively (Fig. 1B). Because V. albo-atrum also is known to encode for the VTP1 gene (19), some homology was observed in in silico NCBI Primer Blast analyses with primer pairs VTP1-2F and VTP1-2R to GenBank sequences of this pathogen. No homology with sequences available for other Verticillium 
spp. was observed. Additionally, amplification was not observed from VTP1-2F/R and PotActF/R assays conducted on common potato pathogens (Table 3). However, an amplicon of the appropriate length was produced with DNA from crucifer pathogen $V$. longisporum. No cross reaction was detected with DNA from the $V$. albo-atrum, V. isaacii, or V. klebahnii. No amplification of a product resulted from tissue-culture-derived greenhouse-reared plantlets evaluated within the VTP1-2 assay or V. dahliae culture DNA with the PotAct assay. The evaluation of VTP1-2F/R using the SYBR Green format resulted in detection of $V$. dahliae at $0.25 \mathrm{pg}$ at a single fluorescence peak, indicating that this assay is both sensitive and specific (Fig. 2).

Development, optimization, and validation of a duplex QPCR assay. Following optimization of the VTP1-2 QPCR assay using the VTP1-2 probe, target DNA was detected in a linear range over six orders of magnitude to a limit of detection (LOD) of 0.25 pg (Fig. 3A). Regression lines developed for each of four $V$. dahliae isolates grown from pure culture resulted in no significant difference among the slopes and intercepts when the Bonferroni adjustment was applied (Table 4). Results from preliminary conventional duplex PCR assays indicated that the two primer sets were amenable to duplexing when compared with individual assays (Fig. 1A-C). Subsequently, all primers and probes were combined to enable the quantification of the target VTP1 gene in a duplex assay normalized via the amplification of the host act gene. When comparing simplex QPCR VTP1-2 to the duplex assay, efficiencies were not compromised when amplifying DNA from $V$. dahliae cultures and tissue-culture-derived plantlets. Therefore, no significant difference was observed in the slope of the simplex VTP1-2 assay when compared with the duplex assay $(P=0.3020)$. Differences were observed in the intercepts of the regression lines $(P<0.0001)$, indicating a decrease in sensitivity from the simplex to the duplex assay. However, amplification of the target and normalizing genes was achieved across five orders of magnitude using the duplex assay. Similar results were achieved with DNA from plants inoculated and grown under greenhouse conditions. Preliminary results from infected tissue indicated that PCR efficiency and regression coefficients were not compromised when compared with the combination of $V$. dahliae from culture and tissue culture plants (Fig. 4A and B).

Comparison of traditional plating to PCR quantification of $V$. dahliae in planta. The quantification of $V$. dahliae using traditional plating and QPCR methods resulted in significant interactions between the main effects of inoculum and cultivar at the first $(P=0.0008 ; P<0.0001)$ and second $(P<0.0001 ; P<0.0001)$ sampling dates. Additionally, at both the first and second sampling dates, significant differences were observed between inoculated and noninoculated plants $(P=0.0187 ; P=0.0033)$, as well as among cultivars $(P=0.0292 ; P=0.0101)$. The interactions between main effects likely were due to seedborne inoculum which resulted in low but varying levels of infection in noninoculated plants (data not shown); therefore, further analysis included comparisons among cultivars for inoculated treatments only.

Among plating assays performed at the first sampling date 8 WAI, significant differences were observed in cube-root-transformed $V$. dahliae $\mathrm{CFU} / \mathrm{g}$ among inoculated cultivars $(P=0.0146)$. Susceptible control Russet Norkotah was most heavily colonized by $V$. dahliae but not significantly more so than moderately susceptible 'Russet Burbank' and very resistant 'Alturas' (Fig. 5A). Resistant control Ranger Russet and Umatilla Russet, 'Premier Russet', and 'Dakota Trailblazer' had moderate levels of $V$. dahliae colonization, significantly less than Russet Norkotah and significantly more than 'Bannock Russet'. At the second sampling date 11 WAI, increases in colonization by $V$. dahliae were observed in most cultivars. Ranger Russet, Umatilla Russet, and Dakota Trailblazer displayed decreases in colonization of 8,16 , and $6 \%$, respectively. Interestingly, Bannock Russet, which had the lowest colonization in the first sampling date, displayed the largest relative colonization increase of nearly $74 \%$ by the second sampling date 3 weeks later. As expected, V. dahliae colonization in the susceptible control Russet Norkotah increased substantially (30\%). Russet Burbank, Alturas, and Premier Russet displayed colonization increases of 24,3 , and $15 \%$, respectively. Overall, this resulted in Russet Norkotah having significantly higher levels of $V$. dahliae colonization than all cultivars except Russet Burbank. Fungal colonization in Bannock Russet was significantly lower than that observed in all other cultivars at both sampling dates.

Employing QPCR methods to the quantification of $V$. dahliae in planta resulted in similar results as observed with traditional plating methods at the first sampling date. Again, susceptible control Russet Norkotah was colonized by $V$. dahliae at the highest level but not significantly more so than resistant control Ranger Russet, or Russet Burbank and Alturas (Fig 5B). The amount of $V$. dahliae

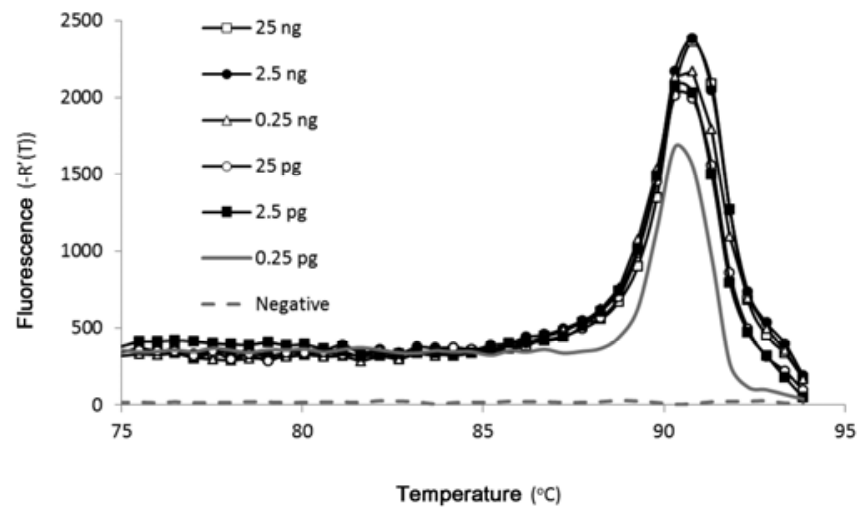

Fig. 2. SYBR green melting curve analysis demonstrating the specificity of the VTP1-2F/R assay to detect the VTP1 gene of Verticillium dahliae isolate VD05MNH5 DNA from pure culture across six orders of magnitude.
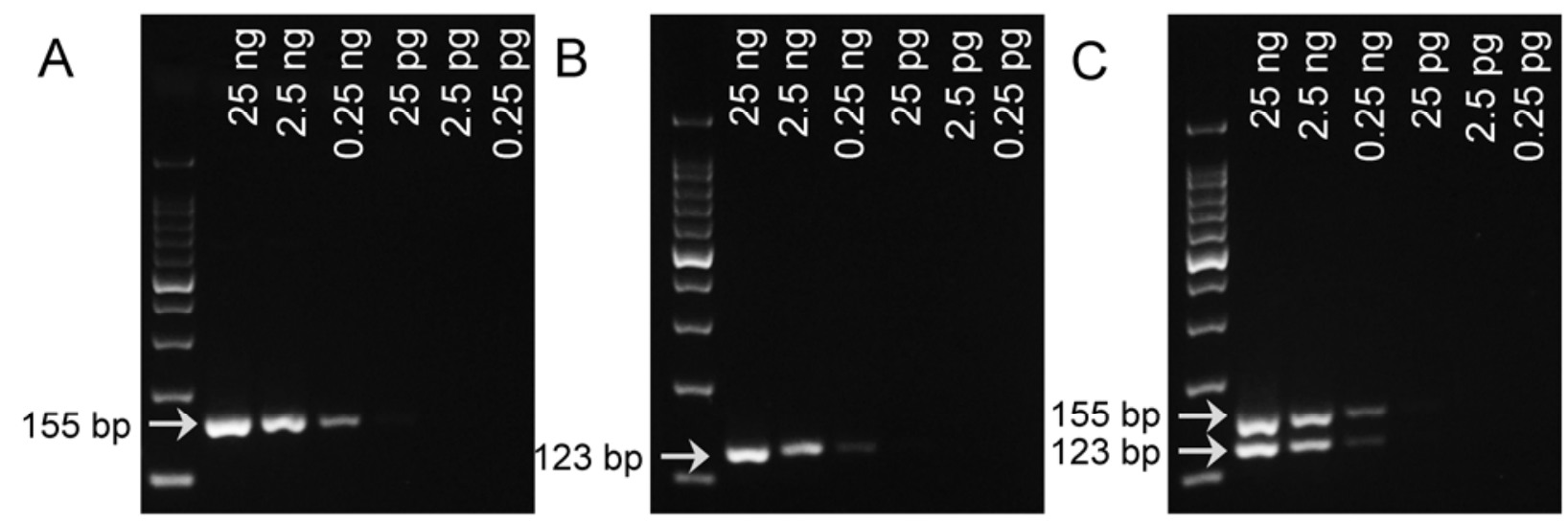

Fig. 1. Conventional endpoint simplex polymerase chain reaction assays using primers A, VTP1-2F/R; B, PotActF/R; and C, the duplex assay with the same primers used to detect serial dilutions of Verticillium dahliae DNA from pure culture and host DNA from greenhouse-reared tissue-culture-derived plantlets across six orders of magnitude. 
DNA quantified from Bannock Russet was significantly lower than all cultivars. Although trends in colonization among cultivars were similar at the second sampling date, the level of increase in $V$. dahliae detected by QPCR methods was much greater than that observed by traditional plating methods. The largest of increases were observed with Bannock Russet (89\%), Umatilla Russet (73\%), Russet Nokotah (69\%), and Russet Burbank (67\%). Alturas and Premier Russet displayed moderate increases of 42 and $27 \%$, respectively, whereas colonization in Dakota Trailblazer increased by only $17 \%$. As was observed with traditional plating assays, colonization decreased in Ranger Russet. With the large relative levels of increases in colonization by $V$. dahliae, significant differences were observed more commonly among cultivars. Significantly higher colonization was observed in Russet Norkotah compared with all other cultivars, followed by Russet Burbank and Alturas. Ranger Russet, Dakota Trailblazer, Bannock Russet, and Premier Russet were colonized at significantly lower levels than all other cultivars. Pearson correlation coefficients indicate that a strong and significant correlation exists between cube-root-transformed data for fungal quantification using traditional and QPCR methods at both the first $(n=16 ; r=0.94 ; P<0.0001)$ and second ( $n=16 ; r=0.96 ; P<0.0001)$ sampling dates.

Comparison of VTP1-2 and VertBt-Plexor assays. The sensitivity of VTP1 and $\beta$-tubulin gene amplification using VTP1-2hybridization probe and VertBt-Plexor assays, respectively, was similar when comparing 10-fold serial dilutions over six orders of magnitude of DNA extracted from fungal mycelium and spores of $V$. dahliae. There also was no difference in LOD across 10-fold serial dilutions over six orders of magnitude of DNA extracted from stem tissue of five plants inoculated with $V$. dahliae in greenhouse trials. Additionally, no significant difference was observed in the slope of the lines generated from assays performed on DNA extracted from each stem sample, indicating that these assays have the same amplification efficiencies. However, regressions analyses indicated that $R^{2}$ values from the VTP1-2-hybridization probe assay $\left(R^{2}=0.992\right.$ to 0.997$)$ were higher than those generated from the VertBt-Plexor assay $\left(R^{2}=0.987\right.$ to 0.991$)$ across dilution series from each of five stem samples. When no DNA dilutions were performed, comparisons between VTP1-2 and VertBt assays resulted in significant differences in the frequency of amplification of $V$. dahliae across greenhouse-inoculated stem samples of Umatilla using both $\chi^{2}(P=0.0033)$ and Fisher's exact analyses $(P=$ 0.0037). The duplex VTP1-2-hybridization probe assay detected $V$. dahliae in inoculated stems at a frequency of $68 \%$, with a mean quantification cycle $(\mathrm{Cq})$ of 31.7 , whereas the duplex VertBt-Plexor assay only detected the pathogen $21 \%$ of the time, with a mean $\mathrm{Cq}$ of 36.3 .

Evaluation of Verticillium wilt severity. Because foliage from all cultivars was confirmed via molecular detection methods to be infected with TSWV in all greenhouse trials, Verticillium wilt was difficult to evaluate accurately. Subsequently, few differences were observed among cultivars, as well as between $V$. dahliae-inoculated and noninoculated plants (Table 5). Susceptible control Russet Norkotah consistently displayed significantly higher levels of RAUWPC in inoculated plants than in noninoculated plants in all three greenhouse trials, and moderately susceptible Russet Burbank displayed higher RAUWPC values in inoculated plants compared with noninoculated plants in two of three trials. However, no significant differences in RAUWPC were observed among the other cultivars with higher levels of resistance to Verticillium wilt.

\section{Discussion}

The importance of Verticillium wilt in potato production is increasing due to several factors, not limited to tuber quality and increased restrictions on metam sodium use for disease control $(38,63)$. Because of the lack of viable alternatives to metam sodium for controlling the disease, the need for resistance in cultivars with acceptable agronomic and end-use consumer qualities is greater than ever $(58,63)$. The evaluation of genetic resistance in breeding selections and cultivars has been based on plating meth- ods in many instances $(4,9,16,24,28-32)$. However, these methods require much greater efforts than can be reasonably justified to screen hundreds of breeding selections on a regular basis (4). As a result, numerous PCR primers and assays have been developed for the detection and quantification of $V$. dahliae $(1,11,25,34,39,40$ $42,48,57)$ but these also have not been utilized for quantification on a large scale. The research reported here was undertaken to improve quantification of $V$. dahliae in planta, by developing a method that could replace plating assays for large-scale evaluations of cultivars and breeding material. The VTPl gene was chosen as the target amplicon for this assay because it was determined to be a single-copy, highly conserved gene in $V$. dahliae isolates from several host plants (19). A duplex assay utilizing an internal nor-

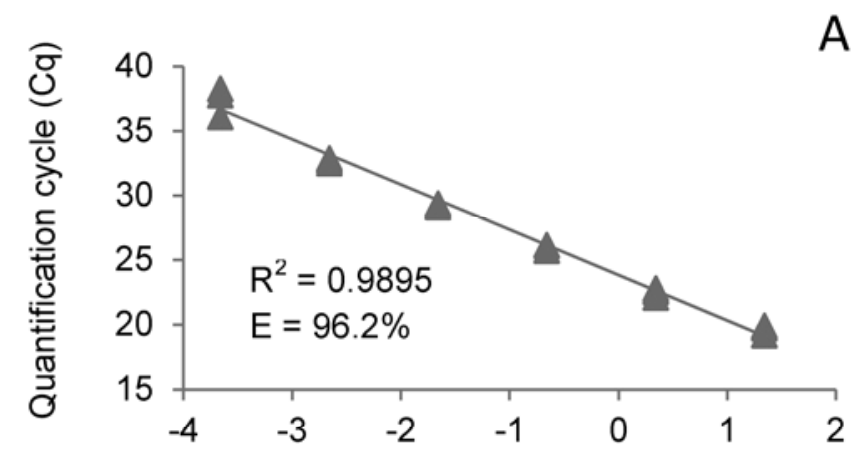

B
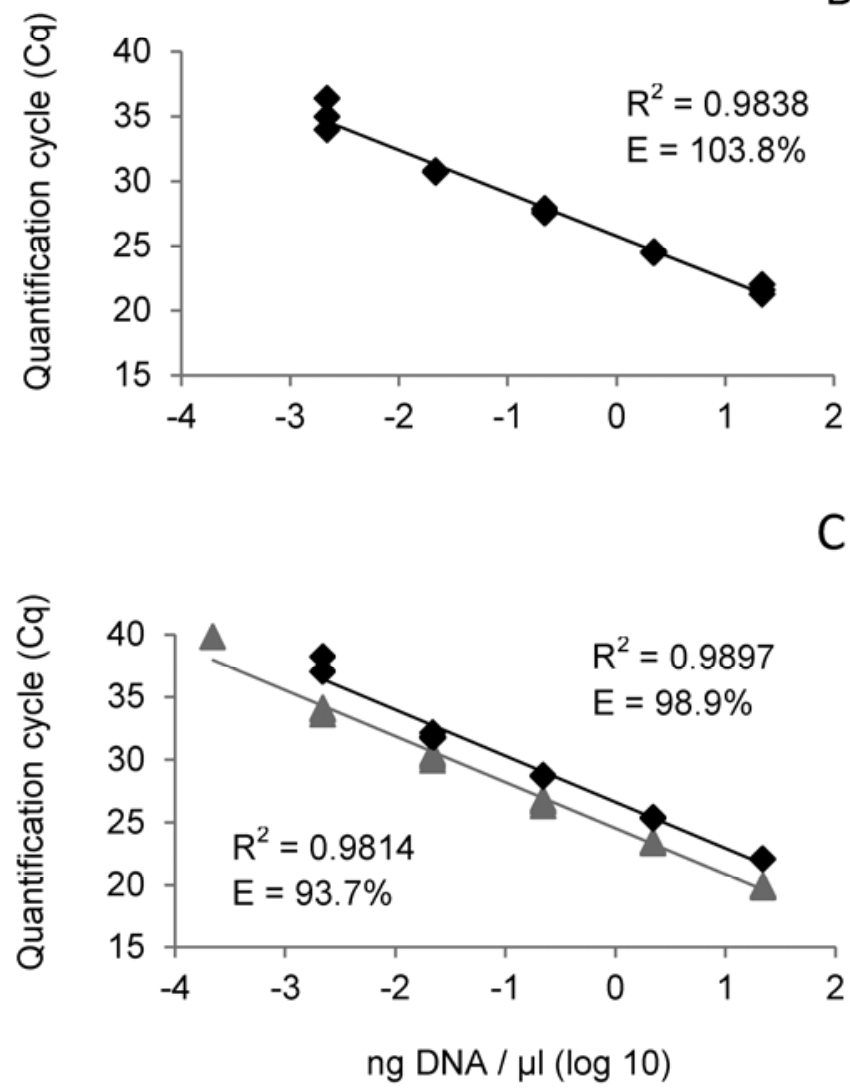

Fig. 3. Standard curve of Verticillium dahliae DNA from pure culture, and DNA extracted from greenhouse-reared, root-inoculated plants of 'Russet Norkotah'. Quantification cycle $(\mathrm{Cq})$ is plotted against log DNA concentration for hybridization probe-based simplex QPCR assays A, VTP1-2F/R/P to detect the VTP1 gene represented by the gray triangle and $\mathrm{B}, \mathrm{PotActF} / \mathrm{R} / \mathrm{P}$ to detect the actin (act) gene, represented by the black diamond, and C, the duplex assay. DNA was diluted serially across six orders of magnitude and the amplification efficiency was calculated using the formula $E=10^{(-1 / \text { slope })}-1$. 
malizing gene from the host reduces the need for evaluating DNA quantity and quality, and helps to control for DNA extraction and PCR efficiency. Additionally, it controls for the presence of PCR inhibitors, because a product should always be produced with the host detection system. Of major importance when developing an assay intended to replace an industry standard is the ability to demonstrate that the novel technique can meet or surpass the performance of existing methods. This QPCR for detection of the $V T P 1$ gene assay was able to detect $V$. dahliae when the plating assay was not. The QPCR described here was $100 \times$ more sensitive when compared with the conventional end-point PCR assay using the same primers, and PCR efficiency and sensitivity remained high in the duplex format, even when evaluating potato stem tissue infected at low levels. Additionally, the use of an amplicon-specific probe may enhance specificity of the assay over non-probe based techniques (8).

The duplex VTP1 assay developed in this research also improved upon detection of $V$. dahliae in planta over the most recent QPCR assay, VertBt-Plexor (1). Russet Norkotah was chosen to evaluate sensitivity across serial dilutions because it is a highly susceptible cultivar and colonization levels were abundant enough to be detected across several orders of magnitude, and no differ- ence was observed between these two assays. However, when DNA extracts were not diluted prior to performing PCR, the VTP1 assay was substantially more sensitive than the VertBt assay. Umatilla Russet was chosen to evaluate sensitivity because it is moderately resistant or moderately susceptible to colonization by $V$. dahliae and, therefore, a wide range of colonization levels existed among greenhouse-inoculated stem tissue. Differentiation between the two assays was possible using this wide range. The authors believe that there may be two explanations for this discrepancy. First, in the original report of these primers, $5 \mu$ of sample DNA was utilized is each QPCR reaction. The VTP1 assay was optimized for use with $2 \mu \mathrm{l}$ of DNA; therefore, to ensure accurate comparisons between the two assays, both were performed on $2 \mu \mathrm{l}$. Second, protocols established for the VertBt system suggested using a DNA clean-up step post extraction to remove PCR inhibitors (1). That step was not required for the VTP1 assay and, therefore, was not performed in comparison assays. The need for removal of inhibitors in the VertBt assay provides a good explanation for why no differences in sensitivity were observed between assays with serial DNA dilutions and significant differences were observed when DNA was not diluted. As the DNA is diluted, so are inhibitors to the reaction, allowing amplification of smaller

Table 4. Linear regression equations obtained using the random coefficients model generated from total genomic DNA extracted from cultures of Verticillium dahliae adjusted to $25 \mathrm{ng} / \mu \mathrm{l}$ diluted serially 10 -fold over six orders of magnitude

\begin{tabular}{|c|c|c|c|c|c|c|}
\hline Isolate & Intercept & $P$ value $^{\mathrm{y}}$ & Slope & $P$ value $^{\mathrm{y}}$ & $\mathbf{A E ^ { \mathbf { z } }}$ & $R^{2}$ \\
\hline VD05MNH5 & 25.42 & 1.1242 & -3.175 & 0.2502 & 106.52 & 0.998 \\
\hline VD05MN1-3 & 25.50 & 0.2395 & -3.301 & 0.4760 & 100.88 & 0.985 \\
\hline VD03UM1 & 26.27 & 0.0340 & -3.345 & 0.1869 & 99.05 & 0.997 \\
\hline VD03UM2 & 25.90 & 0.5674 & -3.192 & 0.3607 & 105.72 & 0.997 \\
\hline
\end{tabular}

y Bonferroni adjustment applied to control the overall of family-wise Type I error for comparisons across parameters $(\alpha=0.006)$.

${ }^{\mathrm{z}}$ Amplification efficiency (AE) was calculated from the slope of each regression line using the equation $\mathrm{AE}=10^{\left(-1 / s^{\prime}\right.}$
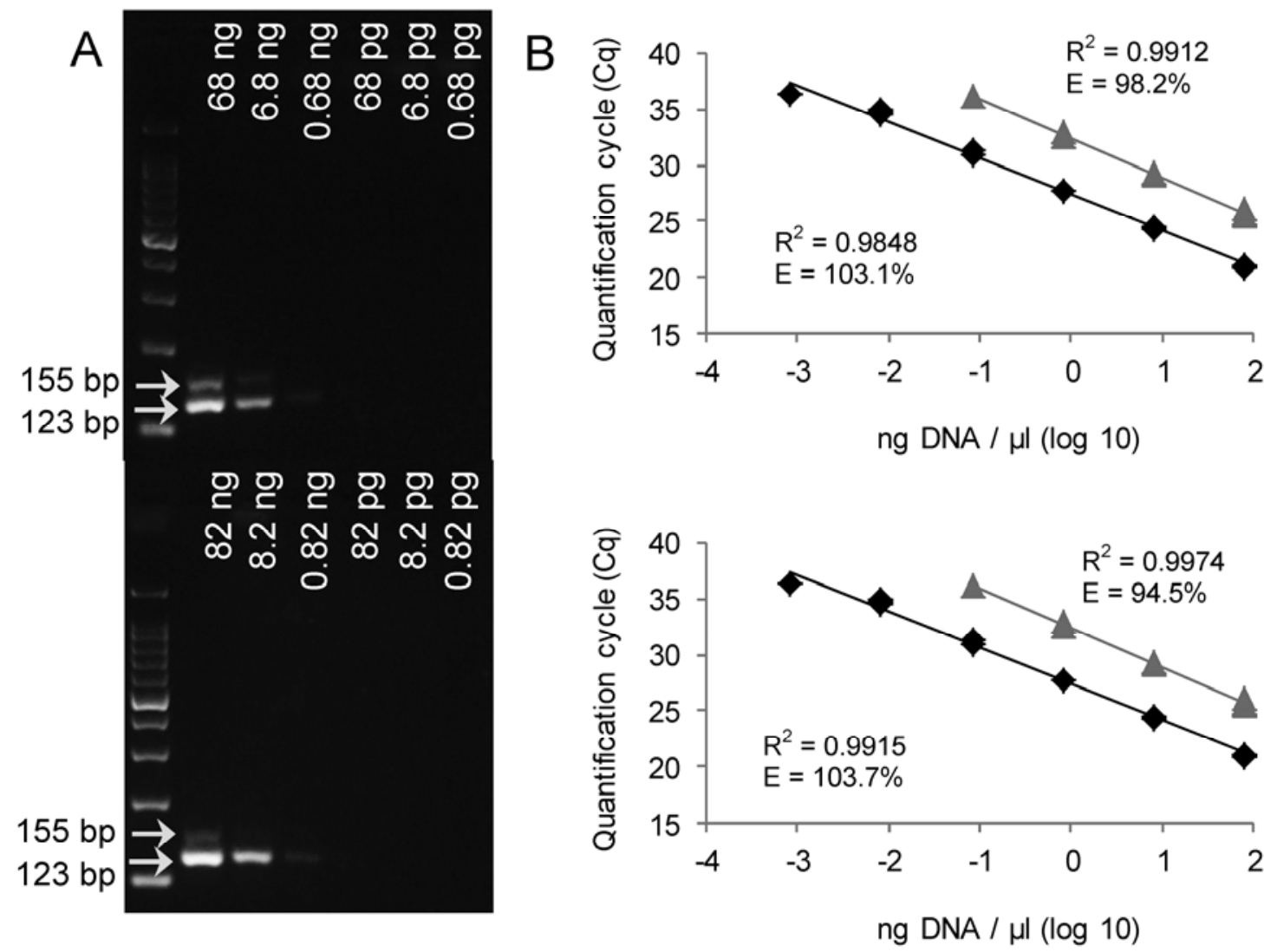

Fig. 4. A, Conventional duplex VTP1-2F/R and B, real-time duplex VTP1-2F/R/P QPCR assays to detect the VTP1 gene from Verticillium dahliae (153 bp), represented by the gray triangle, and the actin (act) gene from potato (123 bp), represented by the black diamond, in two greenhouse-reared, root-inoculated, plants of 'Russet Norkotah'. DNA was serially diluted across six orders of magnitude and the amplification efficiency was calculated using the formula $E=10^{(-1 / \text { slope })}-1$. The same series of dilutions were used for both assays; concentrations are depicted on the gel reproduction. B, Quantification cycle $(\mathrm{Cq})$ is plotted against log DNA concentrations. 
amounts of DNA without inhibition. When no dilutions are performed but only small amounts of DNA are present naturally, the reaction is inhibited and no amplicon is produced. Similar results were observed using the VertBt assay to detect $V$. dahliae in spinach seed. Here, $\mathrm{Cq}$ values for plasmid DNA spiked with DNA extracted from spinach seed purified using AMPure were over 2.5 higher than for plasmid DNA spiked with nonpurified seed DNA. However, only a $0.5 \mathrm{Cq}$ increase was observed when seed was evaluated. The reason for this discrepancy is not clear but does support our findings that inhibitors can be an issue when using the VertBt assay on plant samples containing low levels of the target. The ability to use the VTP1-2 assay without the additional purification step simplifies the procedure, which is a particular benefit to breeders who would potentially be evaluating several hundred lines. Additionally, the VertBt system was evaluated against only two potato cultivars, Russet Norkotah and Ranger Russet, very susceptible and resistant, respectively, to $V$. dahliae (1). In that study, the VertBt assay was able to detect $V$. dahliae colonization in Russet Norkotah but not in Ranger Russet.

The level of increase in colonization in potato stem tissue from the first to the second sampling dates is an important aspect of screening for cultivar resistance. A cultivar which is not colonized rapidly in the first part of the growing season may have higher rates of colonization as the season progresses, resulting in higher colonization levels than other cultivars later in the season, as was determined for Bannock Russet. This reinforces the need for multiple or at least timely evaluations of colonization to accurately assess the level of resistance in a particular cultivar, as well as to estimate the amount of pathogen returned to the soil by a given cultivar. Evaluating cultivars too early in the growing season may result in overestimating the level of resistance in that cultivar. Additionally, evaluations performed too late may provide an assessment of inoculum returned to the soil but may not accurately evaluate the effect the pathogen has on plants during the critical stage of tuberization. Here, the second sampling date (11 WAI) resulted in the best timing to differentiate host resistance. This observation agrees with previous research. which demonstrated increasing differences between colonization of Russet Norkotah compared with Ranger Russet from 2 to 10 WAI (3). Some differences observed at $11 \mathrm{WAI}$ were not as clear at $8 \mathrm{WAI}$; therefore, care should be taken to ensure that colonization is evaluated at the proper timing. For example, results from QPCR assays performed at $8 \mathrm{WAI}$ indicate no significant difference between the susceptible control Russet Norkotah and moderately susceptible Russet Burbank whereas, at 11 WAI, a significant difference in colonization was observed. The optimal timing of evaluation may fluctuate
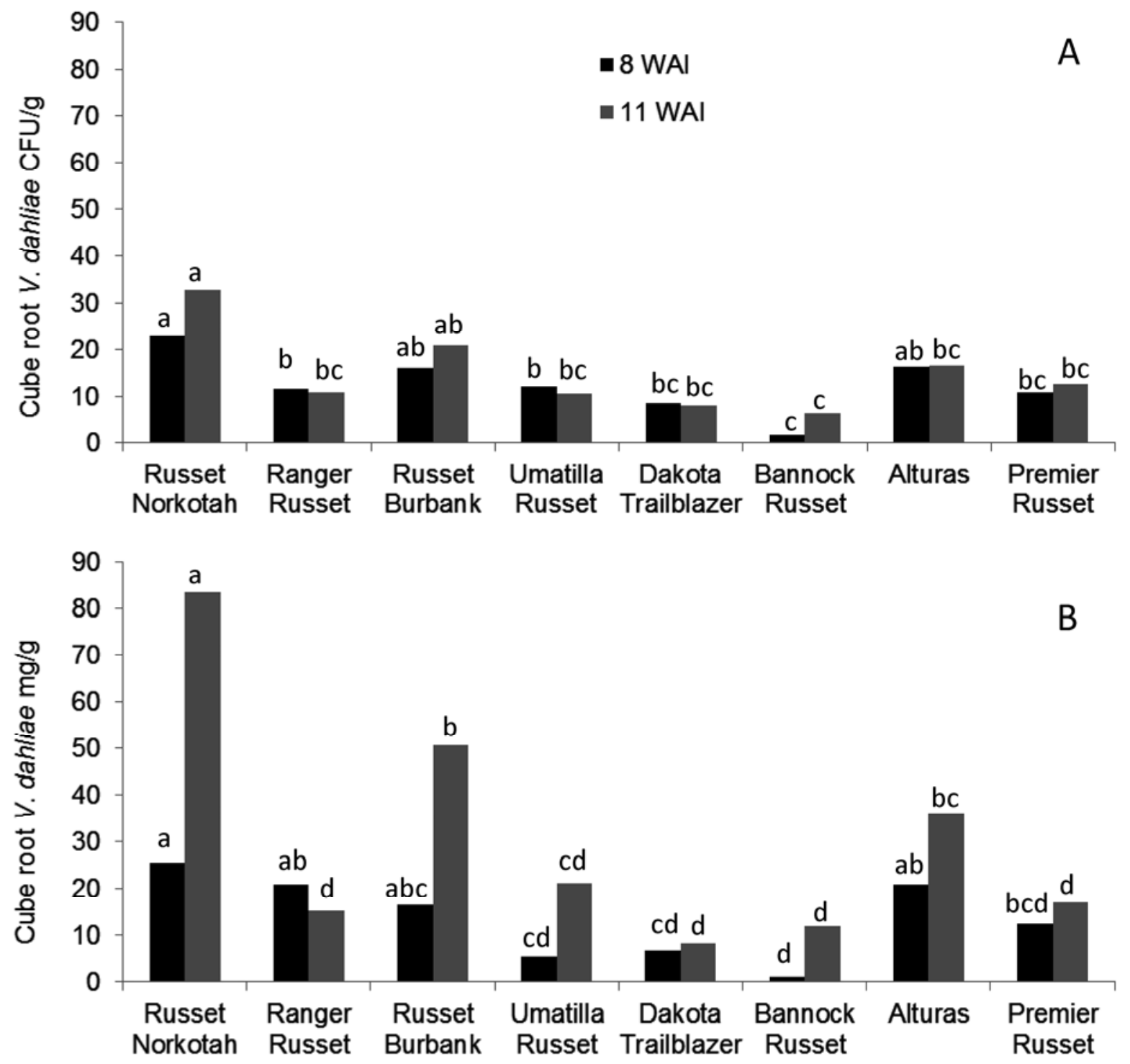

Fig. 5. A, Cube-root-transformed colony forming units of Verticillium dahliae per gram of potato stem tissue (V. dahliae CFU/g) generated using the traditional plating assay and $\mathbf{B}$, milligrams of $V$. dahliae per gram of potato stem tissue ( $V$. dahliae $\mathrm{mg} / \mathrm{g}$ ) generated using the duplex QPCR assay. Evaluations performed 8 and 11 weeks after inoculation (WAI) across eight russet potato cultivars with varying level of resistance to $V$. dahliae. Bars within sampling dates with the same letter are not statistically different based on Fisher's protected least significant difference $(\alpha=0.05)$. 
under varying field conditions and production systems and certainly should be evaluated. Additionally, cultivar maturity has been reported to significantly affect wilt and, in some instances, stem colonization in $V$. dahliae-infested field trials $(4,7,29)$. Strains of Russet Norkotah selected from somatic variants displayed later maturity and lower severity of Verticillium wilt when compared with standard Russet Norkotah (29). Greenhouse trials conducted with 'Kennebec' resulted in a correlation between tuber formation and Verticillium wilt symptoms (7). Plants which were grown under long photoperiods to prevent tuberization also did not display symptoms of Verticillium wilt; however, stem colonization was not evaluated in these trials. When evaluating early-generation breeding selections, stem colonization was significantly correlated with maturity and Verticillium wilt severity in the first year of the field trial but not the second (4). The results reported here demonstrate that colonization can change substantially within a 3-week period under controlled greenhouse conditions; therefore, it would be expected that even greater differences also would be observed under field conditions.

It is the belief of the authors that the larger differences observed between the first and second sampling dates in cultivars with higher colonization levels using QPCR versus plating, including Russet Norkotah, Russet Burbank, and Alturas, were due to an underestimation of colonization using traditional plating methods. In these cultivars, the number of colonies growing on agar media was difficult to differentiate and accurately enumerate. Although colonization in some cultivars was not significantly different than in Russet Norkotah, this most likely is an artifact of the plating assay; in particular, at the second sampling date, when this cultivar was significantly more colonized by $V$. dahliae than all other cultivars evaluated. Data from colonization trials were not normally distributed and required transformation prior to analysis to meet the assumptions of the ANOVA. Very high colonization in susceptible check Russet Norkotah was the main reason for the need for transformation. This especially was true for data generated via QPCR. This issue may be avoided in future studies of this type by using a less susceptible cultivar control such as Russet Burbank. Any cultivar with greater susceptibility to colonization by $V$. dahliae than Russet Burbank would not be acceptable for commercial production. Additionally, the variability in colonization levels in individual stems within and among replicates was somewhat high, also contributing to the need for data transformation (4). This may be attributed to inoculation method, and further investigations of methods which may result in more uniform infection levels currently are underway. The refinement of the in planta assay, in addition to the increased accuracy of the QPCR assay reported here, will result in further improvements in the ability to differentiate levels of resistance to $V$. dahliae in breeding material and cultivars.

Systemic infection of noninoculated plants occurred in greenhouse assays presented here, even though certified seed-tubers were used. This was attributed to seedborne infection, because great care was taken to eliminate contamination during the inoculation procedure. Transmission of $V$. dahliae-infected seed tubers is not a major contributor to overall disease pressure when soilborne inoculum is present; however, seedborne inoculum has been reported to cause Verticillium wilt and systemic fungal colonization $(20,21,61)$. Additionally, it has been shown previously that inoculum on the surface of seed tubers resulted in more wilted plants than did tubers with vascular $V$. dahliae infections (61). Seed tubers were not washed prior to use in greenhouse assays. Washing may have reduced the amount of infection observed in noninoculated treatments and should be considered in future research of this type. Also, the frequency of vascular colonization in seed-tubers was not assessed; therefore, the impact of these two sources of inoculation cannot be evaluated here.

The development and validation of the QPCR assay described here is paramount in the efforts toward breeding for resistance to $V$. dahliae. This assay proved to be sensitive and specific when evaluating greenhouse-produced potato plants exhibiting a wide range of susceptibility to $V$. dahliae. Also, this duplex assay includes the use of a normalizing gene from the host which replaces the need for determining DNA quantity and quality, prior to quantification of the target gene. The target gene of the pathogen was amplified in all cultivars evaluated in this study, even when plating techniques failed to detect the presence of $V$. dahliae. Subsequently, this QPCR assay reduces the time, labor, and expense of quantifying the host-pathogen interaction. Plating assays are limited in that colonies can be difficult to discern in the presence of closely related fungi, as well as in instances when colonization levels are high, possibly resulting in under- and overestimation of fungal quantification. Although QPCR methods do have the limitation of the upper and lower limits of the standard curve, these are much less stringent than those involved with standard plating techniques. Therefore, it serves as a valuable tool for breeders and other researchers in the identification of genetic resistance as well as other control measures for Verticillium wilt.

\section{Acknowledgments}

This work was supported by the United States Department of AgricultureAgricultural Research Service (USDA-ARS) SCA (number 58-3655-0-613) and the Minnesota Area II and Northern Plains Potato Growers Associations. We thank S. Klosterman, USDA-ARS, and K. Subbarao, University of CaliforniaDavis, for generously sharing DNA extracted from isolates of Verticillium spp.; J. Bradeen, University of Minnesota, for providing isolates of $V$. dahliae;

Table 5. Relative area under the wilt progress cure (RAUWPC) generated from greenhouse-reared plants of eight russet-skinned potato cultivars inoculated or not inoculated with Verticillium dahliae ${ }^{z}$

\begin{tabular}{lllll}
\hline Cultivar & Inoculation & Trial 1 & Trial 2 & Trial 3 \\
\hline Russet Norkotah & None & $0.14 \mathrm{c}$ & $0.27 \mathrm{de}$ & $0.43 \mathrm{~b}$ \\
& Yes & $0.30 \mathrm{a}$ & $0.53 \mathrm{a}$ & $0.53 \mathrm{a}$ \\
Ranger Russet & None & $0.31 \mathrm{a}$ & $0.43 \mathrm{~b}$ & $0.56 \mathrm{a}$ \\
& Yes & $0.22 \mathrm{~b}$ & $0.30 \mathrm{~d}$ & $0.41 \mathrm{~b}$ \\
Russet Burbank & None & $0.08 \mathrm{ef}$ & $0.21 \mathrm{ef}$ & $0.18 \mathrm{~d}$ \\
& Yes & $0.09 \mathrm{def}$ & $0.29 \mathrm{~d}$ & $0.33 \mathrm{c}$ \\
Umatilla & None & $0.07 \mathrm{ef}$ & $0.10 \mathrm{~g}$ & $0.10 \mathrm{f}$ \\
& Yes & $0.05 \mathrm{f}$ & $0.11 \mathrm{~g}$ & $0.16 \mathrm{de}$ \\
Dakota Trailblazer & None & $0.08 \mathrm{ef}$ & $0.16 \mathrm{fg}$ & $0.14 \mathrm{de}$ \\
& Yes & $0.08 \mathrm{ef}$ & $0.16 \mathrm{fg}$ & $0.10 \mathrm{ef}$ \\
Bannock & None & $0.09 \mathrm{ef}$ & $0.13 \mathrm{def}$ \\
& Yes & $0.11 \mathrm{cde}$ & $0.19 \mathrm{fg}$ & $0.11 \mathrm{ef}$ \\
Alturas & None & $0.09 \mathrm{def}$ & $0.39 \mathrm{bc}$ & $0.10 \mathrm{ef}$ \\
Premier Russet & Yes & $0.13 \mathrm{~cd}$ cd & $0.15 \mathrm{fg}$ & $<.13 \mathrm{def}$ \\
$P$ value & None & $0.11 \mathrm{cde}$ & $0.11 \mathrm{cde}$ & $<0.0001$ \\
\hline
\end{tabular}

${ }^{\text {z }}$ Values in a column followed by the same letter are not statistically different based on Fisher's protected least significant difference $(\alpha=0.05)$. $P$ value represents the probability of observing a greater value in the $F$ test. 
D. Peterson, R. Benz, and R. Sherman for technical assistance; and C. Doetkott for lending his expertise in statistical analyses.

\section{Literature Cited}

1. Atallah, Z. K., Bae, J., Jansky, S. H., Rouse, D. I., and Stevenson, W. R. 2007. Multiplex real-time quantitative PCR to detect and quantify Verticillium dahliae colonization in potato lines that differ in response to Verticillium wilt. Phytopathology 97:865-872.

2. Atallah, Z. K., and Stevenson, W. R. 2006. A methodology to detect and quantify five pathogens causing potato tuber decay using real-time quantitative PCR. Phytopathology 96:1037-1045.

3. Bae, J., Atallah, Z. K., Jansky, S. H., Rouse, D. I., and Stevenson, W. R. 2007. Colonization dynamics and spatial progression of Verticillium dahliae in individual stems of two potato cultivars with differing responses to potato early dying. Plant Dis. 91:1137-1141.

4. Bae, J., Halterman, D., and Jansky, S. 2008. Development of a molecular marker associated with Verticillium wilt resistance in diploid interspecific potato hybrids. Mol. Breed. 22:61-69.

5. Berbegal, M., Ortega, A., García-Jiménez, J., and Armengol, J. 2007. Inoculum density-disease development relationship in Verticillium wilt of Artichoke caused by Verticillium dahliae. Plant Dis. 91:1131-1136.

6. Bowers, J. H., Nameth, S. T., Riedel, R. M., and Rowe, R. C. 1996. Infection and colonization of potato roots by Verticillium dahliae as affected by Pratylenchus penetrans and P. crenatus. Phytopathology 86:614-621.

7. Busch, L. V., and Edgington, V. 1967. Correlation of photoperiod with tuberization and susceptibility to Verticillium albo-atrum. Can. J. Bot. 45:691-693.

8. Bustin, S. A., and Nolan, T. 2004. Pitfalls of quantitative real-time reversetranscription polymerase chain reaction. J. Biomol. Tech. 15:155-166.

9. Concibido, V. C., Secor, G. A., and Jansky, S. H. 1994. Evaluations of resistance to Verticillium wilt in diploid, wild potato interspecific hybrids. Euphytica 76:145-152.

10. Corsini, D. L., Pavek, J. J., and Davis, J. R. 1988. Verticillium wilt resistance in noncultivated tuber-bearing Solanum species. Plant Dis. 72:148151.

11. Dan, H., Ali-Khan, S. T., and Robb, J. 2001. Use of quantitative PCR diagnostics to identify tolerance and resistance to Verticillium dahliae in potato. Plant Dis. 85:700-705.

12. Davis, J. R. 1985. Approaches to control of potato early dying caused by Verticillium dahliae. Am. Potato J. 62:177-185.

13. Davis, J. R. 2009. Evidence that two Verticillium-resistant potato varieties have the potential to enhance soil suppressiveness toward Verticillium wilt. (Abstr.) Am. J. Potato Res. 86:140.

14. Davis, J. R., and Huisman, O. C. 2001. Verticillium wilt. Pages 45-46 in: Compendium of Potato Diseases. W. R. Stevenson, R. Loria, G. D. Franc, and D. P. Weingartner, eds. American Phytopathological Society, St. Paul, MN.

15. Davis, J. R., Huisman, O. C., Everson, D. O., and Schneider, A. T. 2001. Verticillium wilt of potato: a model of key factors related to disease severity and tuber yield in southeastern Idaho. Am. J. Potato Res. 78:291-300.

16. Davis, J. R., Pavek, J. J., and Corsini, D. L. 1983. A sensitive method for quantifying Verticillium dahliae colonization in plant tissue and evaluating resistance among potato genotypes. Phytopathology 73:1009-1014.

17. Davis, J. R., and Sorenson, L. H. 1986. Influence of soil solarization at moderate temperatures on potato genotypes with differing resistance to Verticillium dahliae. Phytopathology 76:1021-1026.

18. Davis, J. R., Sorensen, L. H., Stark, J. C., and Westermann, D. T. 1990. Fertility and management practices to control Verticillium wilt of the Russet Burbank potato. Am. Potato J. 67:55-65.

19. Dobinson, K. F., Grant, S. J., and Kang, S. 2004. Cloning and targeted disruption, via Agrobacterium tumefaciens-mediated transformation, of a trypsin protease gene from the vascular wilt fungus Verticillium dahliae. Curr. Genet. 45:104-110.

20. Dung, J. K. S., Ingram, J. T., Cummings, T. F., and Johnson, D. A. 2012. Impact of seed lot infection on the development of black dot and Verticillium wilt of potato in Washington. Plant Dis. 96:1179-1184.

21. Dung, J. K. S., and Johnson, D. A. 2012. Roles of infected seed tubers and soilborne inoculum on Verticillium wilt of 'Russet Burbank' potato. Plant Dis. 96:379-383.

22. Duressa, D., Rauscher, G., Koike, S. T., Mou, B., Hayes, R. J., Maruthachalam, K., Subbarao, K. V., and Klosterman, S. J. 2012. A real-time PCR assay for detection and quantification of Verticillium dahliae in spinach seed. Phytopathology 102:443-451.

23. Farley, J. D. 1972. A selective medium for assay of Colletotrichum coccodes in soil. Phytopathology 62:1288-1293.

24. Hoyos, G. P., Lauer, F. I., and Anderson, N. A. 1993. Early detection of Verticillium wilt resistance in a potato breeding program. Am. Potato J. 70:535-541.

25. Hu, X., Nazar, R. N., and Robb, J. 1993. Quantification of Verticillium biomass in wilt disease development. Physiol. Mol. Plant Pathol. 42:23-36.

26. Huisman, O. C., and Gerik, J. S. 1989. Dynamics of colonization of plant roots by Verticillium dahliae and other fungi. Pages 1-17 in: Vascular Wilt Diseases of Plants: Basic Studies and Control. E. C. Tjamos and C. H. Beckman, eds. Springer-Verlag, Berlin.

27. Hunter, D. E., Darling, H. M., Stevenson, F. J., and Cunningham, C. E.
1968. Inheritance of resistance to Verticillium wilt in Wisconsin. Am. Potato J. 45:72-78.

28. Jansky, S. H. 2009. Identification of Verticillium wilt resistance in U.S potato breeding programs. Am. J. Potato Res. 86:504-512.

29. Jansky, S. H., and Miller, J. C. 2010. Evaluation of Verticillium wilt resistance in Russet Norkotah and six strain selections. Am. J. Potato Res. 87:492-496.

30. Jansky, S., and Rouse, D. I. 2000. Identification of potato interspecific hybrids resistant to Verticillium wilt and determination of criteria for resistance assessment. Potato Res. 43:239-251.

31. Jansky, S. H., and Rouse, D. I. 2003. Multiple disease resistance in interspecific hybrids of potato. Plant Dis. 87:266-272.

32. Jansky, S., Rouse, D. I., and Kauth, P. J. 2004. Inheritance of resistance to Verticillium dahliae in diploid interspecific potato hybrids. Plant Dis. 88:1075-1078.

33. Johansen, R. H., Farnsworth, B., Secor, G. A., Gudmestad, N. C., Thompson-Johns, A., and Holm, E. T. 1994. Goldrush: a new high quality russetkinned potato cultivar. Am. Potato J. 71:809-815.

34. Li, K. N., Rouse, D. I., Eyestone, E. J., and German, T. L. 1999. The generation of specific DNA primers using random amplified polymorphic DNA and its application to Verticillium dahliae. Mycol. Res. 103:1361-1368.

35. Love, S. L., Novy, R., Corsini, D. L., Pavek, J. J., Mosley, A. R., Thornton, R. E., James, S. R., and Hane, D. C. 2002. Gem Russet: a long russet potato variety with excellent fresh market and French fry processing quality. Am. Potato J. 79:25-31.

36. Love, S. L., Novy, R. G., Whitworth, J., Corsini, D. L., Pavek, J. J., Mosley, A. R., Pavek, M. J., Knowles, N. R., Brown, C. R., James, S. R., Hane, D. C., and Miller, J. C. 2006. GemStar Russet: a potato variety with high yield, good culinary quality, excellent fresh market appearance, and resistance to common scab. Am. Potato J. 83:171-180.

37. Love, S. L., Novy, R. G., Whitworth, J., Corsini, D. L., Pavek, J. J., Mosley, A. R., Thornton, R. E., Knowles, N. R., James, S. R., and Hane, D. C. 2005. Summit Russet: a new russet potato variety with good fresh market and frozen processing qualities. Am. J. Potato Res. 82:425-432.

38. MacRae, A., and Noling, J. 2010. Overview of new EPA regulations affecting use of metam sodium and metam potassium. Univ. Fla. Ext. HS1167.

39. Mahuku, G. S., Platt, H. W., and Maxwell, P. 1999. Comparison of polymerase chain reaction based methods with plating on media to detect and identify Verticillium wilt pathogens of potato. Can. J. Plant Pathol. 21:125131.

40. Mercado-Blanco, J., Rodríguez-Jurado, D., Parrilla-Araujo, S., and Jiménez-Díaz, R. M. 2003. Simultaneous detection of the defoliating and nondefoliating Verticillium dahliae pathotypes in infected olive plants by duplex, nested polymerase chain reaction. Plant Dis. 87:1487-1494.

41. Mercado-Blanco, J., Rodríguez-Jurado, D., Pérez-Artés, E., and JiménezDíaz, R. M. 2001. Detection of the nondefoliating pathotype of Verticillium dahliae in infected olive plants by nested PCR. Plant Pathol. 50:1-12.

42. Mercado-Blanco, J., Rodríguez-Jurado, D., Pérez-Artés, E., and JiménezDíaz, R. M. 2002. Detection of the defoliating pathotype of Verticillium dahliae in infected olive plants by nested PCR. Eur. J. Plant Pathol. 108:1 13.

43. Miller, P. M. 1955. V8 juice agar as a general purpose medium for fungi and bacteria. Phytopathology 45:460-462.

44. Mosley, A. R., James, S. R., Hane, D. C., Rykbost, K. A., Shock, C. C. Charlton, B. A., Pavek, J. J., Love, S. L., Corsini, D. L., and Thornton, R. E. 1999. Umatilla Russet: a full season long russet for processing and fresh market use. Am. J. Potato Res. 77:83-87.

45. Mosley, A. R., James, S. R., Rykbost, K. A., Hane, D. C., Stranger, C. E., Shock, C. C., Pavek, J. J., Corsini, D. L., Miller, J. C., Love, S. L., Holm, D. G., Thornton, R. E., and Voss, R. E. 2000. Century Russet: a high-yielding fresh market cultivar with Verticillium resistance. Am. Potato J. 77:161-165.

46. Mosley, A. R., Rykbost, K. A., James, S. R., Hane, D. C., Shock, C. C., Charlton, B. A., Pavek, J. J., Love, S. L., Corsini, D. L., and Thornton, R. E. 2001. Klamath Russet: a full season, fresh market, long russet. Am. J. Potato Res. 78:377-381.

47. Navarre, R., Shakya, R., Holden, J., and Crosslin, J. M. 2009. LC-MS Analysis of phenolic compounds in tubers showing Zebra Chip symptoms. Am. J. Potato Res. 86:88-95.

48. Nazar, R. N., Hu, X., Schmidt, J., Culham, D., and Robb, J. 1991. Potential use of PCR-amplified ribosomal intergenic sequences in the detection an differentiation of Verticillium wilt pathogens. Physiol. Mol. Plant Pathol. 39:1-11.

49. Nicot, P. C., and Rouse, D. I. 1987. Relationship between soil inoculum density of Verticillium dahliae and systemic colonization of potato stems in commercial fields over time. Phytopathology 77:1346-1355.

50. Nnodu, E. C., and Harrison, M. D. 1979. The relationship between Verticillium albo-atrum inoculum density and potato yield. Am. J. Potato Res. 56:11-25.

51. Novy, R. G., Corsini, D. L., Love, S. L., Pavek, J. J., Mosley, A. R., James, S. R., Hane, D. C., Shock, C. C., Rykbost, K. A., Brown, C. R., and Thornton, R. E. 2002. Bannock Russet: a dual-purpose, russet potato cultivar with high U.S. No. 1 yield and multiple disease resistances. Am. J. Potato Res. 79:147-153

52. Novy, R. G., Corsini, D. L., Love, S. L., Pavek, J. J., Mosley, A. R., James, 
S. R., Hane, D. C., Shock, C. C., Rykbost, K. A., Brown, C. R., and Thornton, R. E. 2003. Alturas: a multi-purpose, russet potato cultivar with high yield and tuber specific gravity. Am. J. Potato Res. 80:295-301.

53. Novy, R. G., Love, S. L., Corsini, D. L., Pavek, J. J., Whitworth, J. L., Mosely, A. R., James, S. R., Hane, D. C., Shock, C. C., Rykbost, K. A., Brown, C. R., Thornton, R. E., Knowles, N. R., Pavek, M. J., Olsen, N., and Inglis, D. A. 2006. Defender: a high-yielding, processing potato cultivar with foliar and tuber resistance to late blight. Am. Potato J. 83:9-19.

54. Novy, R. G., Whitworth, J. L., Stark, J. C., Love, S. L., Corsini, D. L., Pavek, J. J., Vales, M. L., James, S. R., Hane, D. C., Shock, C. C., Charlton, B. A., Brown, C. R., Knowles, N. R., Pavek, M. J., Brandt, T. L., Gupta, S., and Olsen, N. 2010. Clearwater Russet: a dual purpose cultivar with cold sweetening resistance, high protein content, and low incidence of external defects and sugar ends. Am. Potato J. 87:458-471.

55. Novy, R. G., Whitworth, J. L., Stark, J. C., Love, S. L., Corsini, D. L., Pavek, J. J., Vales, M. I., James, S. R., Hane, D. C., Shock, C. C., Charlton, B. A., Brown, C. R., Knowles, N. R., Pavek, M. J., Brandt, T. L., and Olsen, N. 2008. Premier Russet: a dual purpose, potato cultivar with significant resistance to low temperature sweetening during long-term storage. Am. J. Potato Res. 85:198-209.

56. Otazu, V., Gudmestad, N. C., and Zink, R. T., 1978. The role of Colletotrichum atramentarium in the potato wilt complex in North Dakota. Plant Dis. Rep. 62:847-851.

57. Pérez-Artés, E., García-Pedrajas, M. D., Bejarano-Alcázar, J., and JiménezDíaz, R. M. 2000. Differentiation of cotton-defoliating and nondefoliating pathotypes of Verticillium dahliae by RAPD and specific PCR analyses. Eur. J. Plant Pathol. 106:507-517.

58. Powelson, M. L., Johnson, K. B., and Rowe, R. C. 1993. Management of diseases caused by soilborne pathogens. Pages 149-151 in: Potato Health Management. R. C. Rowe, ed. American Phytopathological Society, St. Paul, MN.

59. Powelson, M. L., and Rowe, R. C. 1993. Biology and management of early dying of potatoes. Annu. Rev. Phytopathol. 31:111-126.

60. Powelson, M. L., and Rowe, R. C. 1994. Potato early dying: causes and management tactics in the eastern and western United States. Pages 178 190 in: Advances in Potato Pest Biology and Management. G. W. Zehnder, M. L. Powelson, R. K. Jansson, and K. V. Raman, eds. American Phytopathological Society, St. Paul, MN.

61. Robinson, D. B., and Ayers, G. W. 1961. Verticillium wilt of potato in relation to vascular infection of the tuber. Can. J. Plant Sci. 41:703-708.

62. Rowe, R. C. 1985. Potato early dying-a serious threat to the potato industry. Am. Potato J. 62:157-161

63. Rowe, R. C., and Powelson, M. L. 2002. Potato early dying: management challenges in a changing production environment. Plant Dis. 86:1184-1193.

64. Shaner, G., and Finney, R. E. 1977. The effect of nitrogen fertilization on the expression of slow-mildewing resistance in Knox wheat. Phytopathology 67:1051-1056.

65. Stark, J. C., Novy, R. G., Whitworth, J. L., Love, S. L., Corsini, D. L., Pavek, J. J., Vales, M. I., James, S. R., Hane, D. C., Charlton, B. A., Brown, C. R., Knowles, N. R., Pavek, M. J., and Brandt, T. L. 2009. Highland Russet: a full season, processing variety with high yields of uniform U.S. no. 1 tubers. Am. Potato J. 86:171-182.

66. Taylor, R. J., Pasche, J. S., and Gudmestad, N. C. 2005. Influence of tillage and method of metam sodium application on distribution and survival of Verticillium dahliae in the soil and the development of Verticillium wilt of potato. Am. J. Potato Res. 82:451-461.

67. Tsompana, M., Abad, J., Purugganan, M., and Moyer, J. W. 2005. The molecular population genetics of the Tomato spotted wilt virus (TSWV) genome. Mol. Ecol. 14:53-66.

68. Westfall, P. H., Tobias, R. D., Rom, D., Wolfinger, R. D., and Hochberg, Y. 1999. Chapter 2: Concepts in basic methods for multiple comparisons and tests. Pages 13-40 in: Multiple Comparisons and Multiple Tests. SAS Institute, Inc., Cary, NC

69. Wilhelm, S. 1955. Longevity of Verticillium wilt fungus in the laboratory and field. Phytopathology 45:180-181.

70. Xiao, C. L., and Subbarao, K. V. 1998. Relationships between Verticillium dahliae inoculum density and wilt incidence, severity, and growth of cauliflower. Phytopathology 88:1108-1115. 